\title{
Os caminhos de Wagner da Conceição Pinto na luz cênica
}

\section{Wagner da Conceição Pinto's paths in scenic light}

Entrevista com Wagner da Conceição Pinto concedida à Ivo Godois ${ }^{2}$ 


\section{Resumo}

Esta entrevista foi realizada no dia 06 de setembro de 2019, durante o evento A Luz em Cena, realizado de 02 a 06 de setembro de 2019 no Centro de Artes (CEART), da Universidade do Estado de Santa Catarina (UDESC). Nela procurou-se levantar pontos que explicitassem o processo formativo de Wagner da Conceição enquanto iluminador cênico.

Palavras-chaves: Iluminador; aprendizado da luz cênica, iluminação cênica

\section{Abstract}

ThisinterviewwasheldonSeptember 6, 2019, during the event A Luz em Cena, held from September 2 to 6, 2019 at the Arts Center (CEART), of the State University of Santa Catarina (UDESC). It sought to raise points that explained the formative process of Wagner da Conceição as a scenic illuminator.

Keywords: Illuminator; learning scenic light, scenic lighting

E-ISSN: 2358.6958

\footnotetext{
1 Doutorando do Programa de Pós-graduação em Teatro, da Universidade do Estado de Santa Catarina (UDESC), onde é técnico de iluminação do Centro de Artes e do Curso de Licenciatura em Teatro. ivogodo@gmail.com
} 


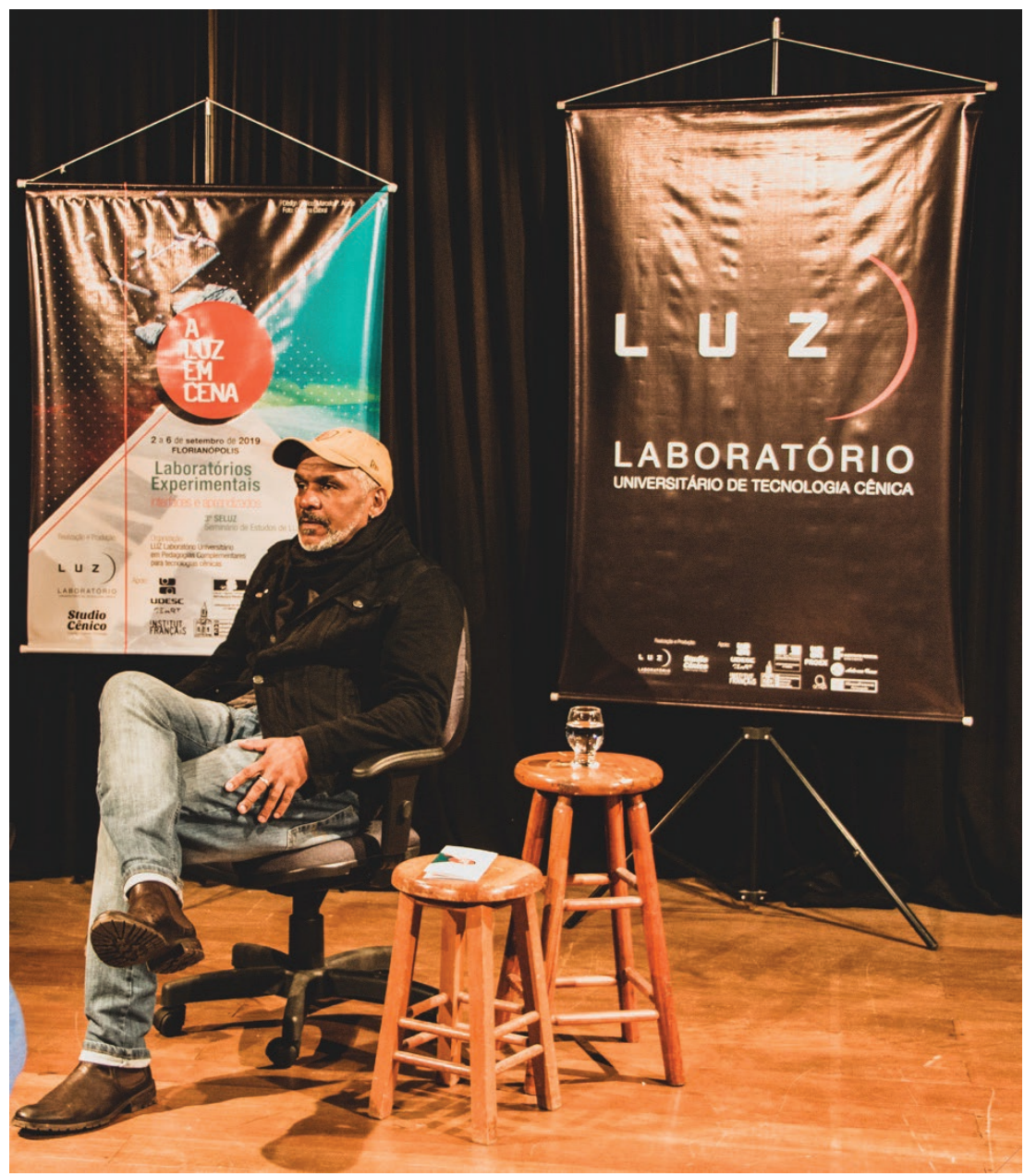

Wagner da Conceição Pinto

Wagner Pinto é um pernambucariocalista, nascido em 1965, em Recife. Mas, não fui registrado em Recife, fui registrado no Rio de Janeiro por isso toda a minha documentação é do Rio. Minha mãe me levou com dois meses de idade, então eu me considero um carioca em todos os sentidos, mas por isso que eu digo que sou um pernambucariocalista, porque Pernambuco como estado, Rio de Janeiro como segundo estado, e São Paulo como terceiro estado e eterno. Que é meu amor, minha casa minha vida, hoje em dia eu vivo em São Paulo muito mais tempo do que eu tenho de Rio de janeiro vinte anos. No Rio de Janeiro eu morei até os vinte e um anos, e depois disso São Paulo. Então eu tenho trinta e três anos morando em São Paulo.

Minha história começa muito na contramão do que é estar em teatro, a busca pelo teatro, qualquer coisa nesse sentido. Minha mãe ela é camareira, e até hoje ela é camareira. O nome dela é Ilda Maria, mais conhecida no mercado como Sônia e é Soninha e nunca mais isso mudou. Eu remava, e depois de um tempo eu remando, ela precisou de apoio financeiro, essa coisa toda porque meu pai eu não conheci. Tem um detalhe, meu pai foi campeão pan-americano de box em 1966, e dentro dessa história toda, como ganhou a medalha de ouro, ele simplesmente...Como todos, acontece na vida, foi embora. E com isso Soninha ou llda começou a tomar conta, eu e meu irmão. Eu tenho um irmão Valdir e uma irmã Flavia que veio nove anos depois, de um outro casamento. E nessa história ela me pediu uma força, eu disse tudo bem, 
agora está na hora, é uma troca. Eu fiquei um pouco triste porque eu remava e já estava no caminho de atleta e seguir o meu DNA de medalhas do meu pai.

\section{Quantos anos você tinha?}

Eu tinha de treze para quatorze anos quando comecei a remar, remei durante três anos, dos meus quatorze até meus dezessete, e é quando ela pede o help, e nisso ela falou, olha eu preciso da tua força, eu estou fazendo um espetáculo no Teatro do Quatro, chama-se As Lágrimas Amargas de Petra Von Kant com Fernanda Montenegro, Renata Sorrah, Juliana Carneiro. E precisava de um assistente de contrarregra, dai eu disse, mas mãe, assistente de contrarregra, eu não sou muito, a senhora sabe que eu não tenho muito envolvimento com o teatro, mas se tivesse a possibilidade de trabalhar com luz, aí sim eu ficaria. Ela disse, olha você começa como assistente, e depois, o Aurélio de Simoni que trabalha no espetáculo, você vai conhecer ele e de repente ele pode te chamar para trabalhar em alguma coisa do gênero. Eu disse tudo bem, é um começo e a senhora está precisando de uma força e eu fui.

Como minha mãe era camareira, ela me levou para ver vários espetáculos. Um infantil que me marcou muito foi Don Quixote no teatro SESC Tijucas, o ano eu não consigo recordar direito mas acredito que eu tinha uns dez para onze, onze para doze anos. Eu fiquei fascinado olhando, eu não olhava para a cena, eu olhava para cima, eu falava: como isso troca de cor? Como isso acende? [...] me chamou a atenção [...] nosso isso é mágico, isso é interessante, tem cores, como é que isso trabalha, como é que se constrói cenas, uma hora branco, outra hora azul, outra hora esta totalmente escuro, as vezes só tem um foco no rosto, como é que essa magia acontece?

E eu troquei com ela, eu disse: eu aceito fazer a assistência de contrarregra, começar com isso e tentar então chegar nesse objetivo que era a luz. E com o tempo, a gente ficou com o espetáculo dois anos em horário alternativo e depois mais um ano e meio em horário nobre. E nesse percurso de dois anos o Aurélio trabalhava, fez a luz do espetáculo junto com o Neném (Luiz Paulo) e Aurélio Simoni, eu como assistente, ele operando a luz, teve um dia que ele chegou e disse, você não quer chegar mais cedo amanhã para me dar uma força? Eu preciso trocar umas lâmpadas. Eu disse: tudo bem Aurélio, eu chego. Porque eu já estava sentido que era o caminho de estar lá. Mas, o mais interessante que antes disso eu comecei a ficar tão curioso que eu chegava na cabine e perguntava para ele, Aurélio como é que funciona? Ele falava assim: isso é assim, é assim, você liga aqui, isso aqui é o PBX, você liga o que está na tomada, você liga nesse quadro e esse quadro está aqui nesses canalzinhos, e você vai levantando os botões e é assim que funciona.

Eu achei aquilo muito, eu estou tão apaixonado pela coisa, eu acho que não consegui me expressar direito para ele entender que eu estava curioso realmente, e deixei passar. Depois de um tempo, acho que uns dois ou três meses depois, é que ele me chama para chegar mais cedo para ajudar a trocar as lâmpadas dos refletores que estavam queimados. O mais curioso disso, que quem avisava ele que estava queimado era Fernanda Montenegro. Porque ela sabe tudo de palco, ela falou: olha Aurélio, acho que tem um refletor na ponta e um outro ali que está... 
E como o teatro era semi-arena, e a visão da cabine não permitia que ele [visse] eu falei: tudo bem, vamos trocar. Eu falei: você quer que eu suba ou você sobe. Ele disse: não você ainda não sabe subir em escada, você não pode, quando eu pedir você levanta o canal dois. Eu falei, hum... minha hora de mexer nesse brinquedinho, aí eu levantei. Todas as vezes que queimava, isso levou uns três meses, queimando e eu ajudando, ele disse: você chega mais cedo. Ele me explicou como é que se fazia para passar a luz, mas se não estiver acendendo você marca e fala Aurélio este não esta acendendo, porque a lâmpada queimou e nós trocamos. Não troca sozinho, porque você ainda não sabe, não pode subir escada.

E começou um processo de ele ficar dizendo: agora que você esta entendendo um pouco melhor, de trabalhar comigo; eu estou precisando, eu e o Neném estamos em um processo louco de trabalho, você não quer aprender? Eu falei: é só o que eu quero Aurélio. Então, disse ele: a partir de agora você está trabalhando com a gente. Mas aí ele falou, você não pode sair ainda do espetáculo, porque a gente não tem condições de ficar te bancando com salário e essas coisas todas, então você vai ser um freelance.

E o mais curioso que, bom eu acho que isso já vem desde 1960, desde Ziembinski, a gente não tinha um espaço de luxo como se tem hoje, durante o dia. Durante o dia, que eu me lembre em 1982, que foi quando eu comecei, era, de manhã você montava o cenário, durante a tarde você ensaiava das cinco da tarde até as dez ou onze da noite e você só tinha a noite, ou seja, era sempre virada. E de vez em quando você conseguia em alguns horários que o cenário já estava acabando, você entrava de manhã. Geralmente, a gente montava sempre a noite, sempre. Eu virei muitas noites, muitas noites para aprender a brincadeira.

O primeiro espetáculo que me marcou, foi o Rei Lear, no Teatro Clara Nunes, isso em 1983, no shopping da Gávea no Rio de Janeiro. A equipe era eu, o Maneco (Quinderé), o sobrinho do Aurélio e mais o Dentinho. O Aurélio chegou e falou: olha gente, é uma empreitada de muito tempo que a gente tem de refazer todo o cenário do Paulo Mamedi, era cheio de mangueiras e tudo mais, era muito complicado. Na época não se usava lâmpada PAR 64 nas cenas, no teatro, o que se usava era o cilibrim que era o farol de fusca. Ele era $12 \mathrm{v}$ e você tinha que ligar sempre ou para fazer $110 v$ você ligava 10 ou 220v você tinha que ligar 20 para poder chegar na soma da voltagem. Isso foi o que mais me impressionou, a criatividade que eles tinham de pegar lâmpadas que não tinha a ver com as cenas, porque na época a gente não tinha muito essa história do elipsoidal, muito pelo contrário, os elipsos foram entrar em 1987 ou 1988, se eu não me engano com muito mais força na cena do teatro. Aquela montagem me deixou fascinado, mas ao mesmo tempo me deixou muito desgastado, e minha mãe pediu para eu parar. Ela falou: Wagner desculpa, mas eu acho que eu errei porque você não está mais parando em casa, você não está mais tendo vida. Porque a gente saía de uma montagem e ia para outra. Eu saia de Lágrimas Amargas e virava a noite, ou seja, eu ficava praticamente vinte e quatro horas dentro da caixa. Isso com meus dezessete, dezoito anos, no final eu acabei operando, eu operei por um ano e dois meses.

O Aurélio me passou todos os passos de como se opera uma luz ele chegava e ensaiava comigo. Dizia: olha a sua mão tem de ser muito leve. A luz ela não entra, a 
luz acontece, a luz é uma mágica, e foi isso que te trouxe para cá, que eu me lembro que você me falou do espetáculo infantil que você assistiu. Esta mágica esta aqui, esta na sua mão, você tem esse controle, se você tiver uma mão leve, se você tiver uma sensibilidade de entender do que está na cena com esta mesa, eu tenho certeza que você vai decolar. E fiquei, um ano e dois meses operando esta luz e depois eles me chamaram, o Dentinho iria operar o Rei Lear e não deu certo, porque não conseguiu, porque na época era muita coisa a gente tinha pouca mesa para muito equipamento.

Hoje em dia você não tem mais isso, mas naquela época a gente trabalhava com um quadro de cruzamento, que eram silentoques em que você transformava um canal em vinte canais. Não poderia ligar todos estes silentoques ao mesmo tempo se não, nem o fio aguentava, porque a amperagem dele não iria aguentar e iria estourar e queimar. Você tinha que ficar fazendo em cada cena que passava se você não usou mais desliga e ligou outro e vem e assim era.

Eu tinha um quadro de cruzamento com mais ou menos umas cinquentas teclas, tinha a mesa que tinha quarenta e oito canais e do lado tinha mais esse quadro com cinquenta teclas que o Neném (Luiz Paulo) inventou. Isso foi a ideia do Neném, para poder solucionar a nossa dificuldade. O Dentinho não conseguiu assimilar, o Aurélio chegou e falou: porque você não chama o Wagner? O Neném respondeu: Aurélio é uma pressão, o Wagner ainda não está pronto, vai ser uma pressão muito grande para ele, eu acho que a gente vai pular uma etapa. O Aurélio: Não eu acho que ele esta super pronto, você já viu ele operando As Lágrimas? Neném respondeu: As Lágrimas ele levou um tempo e aqui a gente não tem tempo. Aurélio: Eu tenho certeza, se você chamar ele vai chegar cedo, ele vai dar o jeito dele, mas ele vai conseguir fazer, e é uma forma dele se sentir querido no nosso trabalho, com a gente nesta parceria para levar para algum lugar porque eu acho que ele tem futuro.

O Aurélio sempre falou isso para mim: eu acho que você tem futuro neguinho, só não perca a cabeça. Eu era novo com dezessete anos, não perca a cabeça, não desvie seu pensamento, não se envolva com o que vai ver na cena, porque a cena realmente é muito forte, é muitas drogas, é muito tudo. Não se envolva nisso e siga a sua carreira que eu tenho certeza que você chega lá.

E eu querendo muito, querendo muito, querendo muito. Um belo dia eu estou no Teatro dos Quatro e o Neném chega e fala: neguinho, amanhã é possível você chegar por volta das duas da tarde aqui no teatro? Eu: sim porque? Você vai precisar... queimou alguma lâmpada aqui? Neném: Não, não é neste teatro, é no teatro Clara Nunes. Eu: eu chego as duas horas da tarde. E aí chegamos e eu falei: Então o que precisa, a gente vai trocar lâmpadas, o que aconteceu? Ele: Não, você vai sentar e talvez você opere esse espetáculo, você vai começar operando comigo, eu aí do teu lado, mas, depois eu não vou poder fazer, porque a gente já tem um próximo trabalho e você vai dominar isso. Eu falei: Esta bom. Tremi na base na hora do convite, mas ao mesmo tempo querendo muito, a gana de aprender e querer ser o cara. E comecei a treinar, e treinar com ele e tudo mais. O diretor do espetáculo era o Celso Nunes. $O$ elenco era muito grande, eu não lembro mais muito bem, mas tinha Fernanda Torres, Ariclê Perez, Sérgio Brito. 


\section{O nome do espetáculo era?}

O Rei Lear, e mais quem...Nossa tinha uma nata, sempre teatro igual a Globo. Era muito complicado, realmente era muito, muito complicado mesmo, porque eles enlouqueceram. Tinha uma batalha, eu me lembro como se fosse hoje, e nessa bataIha tudo era muito preciso, e era onde entravam estes cilibrim, tanto nas mangueiras fazendo uns raios, como em uma bateria de frente que quando eles se encontravam aquilo vinha, tinha uma bateria com vinte cilibrim, de frente uma luz muito forte, que vinha e na hora eles batiam as espadas, batiam os escudos eu precisava acertar aquilo.

E nesses ensaios o Celso Nunes foi assistir e ele sentiu a minha mão ainda um pouco dura para o espetáculo, porque eu estava começando a brincadeira. Aí o Neném disse: Calma, dá um tempo para ele. Ele disse: Não, mas ele não vai conseguir, ele não vai conseguir, ele não vai conseguir... mas tudo bem, eu vou dar mais uma semana, se ele não conseguir em uma semana a gente troca o operador.

O Neném me explicou tudo isso. Eu chegava, ao invés de chegar as duas, eu já chegava as onze da manha no teatro e saia do teatro por volta de quinze para a meia noite, ou seja, doze horas na função, porque nesta semana era o meu teste assim, minha prova de fogo. Eu falei, bom agora é trabalhar e trabalhar e trabalhar. Eu chegava e depois todo mundo ia chegando e diziam, mas você já está aqui? Eu dizia é que eu já estou aqui desde as onze horas da manhã, mas fazendo o que? Eu dizia ensaiando, ensaiando, mas não precisa ensaiar, você está fazendo super bem, eu falei não, não, não. O Celso não acha que eu estou fazendo muito bem.

Dai quando ele veio para assistir ao espetáculo, que era a prova de fogo mesmo. Ele ficou atrás, e eu comecei a tremer porque ele estava bem atrás, ele não estava na plateia, porque a cabine a gente colocou num camarote, e ele não estava na plateia, o que me deixaria mais tranquilo, mas ele ficou bem atrás de mim, ele estava atrás e aquilo me deixou muito, muito assustado, muito nervoso mas correu tudo bem, terminou o espetáculo e ele me deu um abraço e disse: Pô desculpa por não ter confiado. Parabéns, você fez super bem.

E aquilo me marcou muito, eu falei: nossa, isso não é brincadeira, isso é sério. Eu quero ser o que estes caras são, o Aurélio e o Neném, eu quero criar. Eu quero chegar neste patamar, mas eu sabia que tinha que ter estrada ainda, eu sabia que ainda tinha que ter chão. E com isso a gente começou, e foi, montagem e Jimba. Porque na época o eletricista era chamado de Jimba, todo mundo que começava era chamado de Jimba. E tem uma coisa muito engraçada, que quando eu fui operar de verdade este espetáculo, o Sergio Brito perguntou se eu tinha garalhufa.

\section{O que é garalhufa}

Exatamente, o que é garalhufa? Eu disse não, eu não sei o que é garalhufa. Dai ele disse: você precisa de uma garalhufa senão você não vai poder fazer este espetáculo. Eu falei: nossa como é que eu faço para conseguir uma garalhufa eu compro 
uma garalhufa? Ele: não, não compra uma garalhufa, você tem que pedir para um técnico que está acima de você há muito mais tempo. O Aurélio e o Neném não podem te dar porque eles são teus professores, mas o Jorginho pode te dar uma garaIhufa, o José Augusto pode te dar uma garalhufa.

Eu fui atrás desta garalhufa e fui perguntar ao Zé (José Augusto), porque o Zé trabalhava muito com a gente. Procurei e falei: Zé Augusto eu preciso de uma garalhufa, como é que eu consigo uma garalhufa, se eu não conseguir, eu não poderei operar (a luz do) espetáculo. Ele: O Wagner, você vai ter de ir no Teatro Municipal procurar o Secreto, é o Secreto que tem.

Lá fui eu para o Teatro Municipal procurar o Secreto para conseguir a garalhufa. Quando eu chego no teatro, o Secreto mandou eu subir no urdimento que tem mais ou menos uns trinta e cinco metros ou quarenta metros de altura do palco até chegar no urdimento. Eu fiquei procurando a garalhufa e procurei, procurei, procurei. Tinha uma coisa meio esquisita que eu não sabia o que era. E pensei: deve ser isso e desci com a garalhufa. Achando que era a garalhufa. E ele disse: Não, não é isso não, você tem de procurar melhor. Eu fiquei mais ou menos umas três horas procurando a garalhufa. Quando eu começo a descer as escadas, tinha uma galera lá embaixo rindo, rindo, rindo. Eu falei: o que é que está acontecendo, qual é a piada? Simplesmente garalhufa não existia, era uma pegadinha. Nunca existiu a garalhufa, nada, era só uma pegadinha que se tinha antigamente. Hoje em dia não existe mais porque o povo acabou com esta brincadeira. Depois desse episódio, eu voltei e disse: Poxa, que sacanagem Sérgio. Ele disse: Mas você conseguiu a sua garalhufa, você agora sabe, então na próxima você passa adiante. Porque isso é uma brincadeira que a gente vai passando para os iniciantes.

Depois desse trabalho eu fiquei como fixo do Teatro dos Quatro. Aí começa minha história para valer, eu começo a levar muito mais a sério porque vem as produções dentro do teatro. Nessa época, isso se eu não me engano foi em 1982 para 1983. A Lágrimas Amargas já foi produzida no projeto Shell. O projeto Shell produzia os espetáculos. O Teatro dos Quatro, se eu não me engano foi o primeiro teatro a conseguir um patrocínio de três montagens pelo projeto Shell. A primeira foi Lágrimas Amargas, a segunda foi Tio Vânia, com direção do Sérgio Brito, e a terceira foi uma com a lara Amaral, esta me fugindo o nome agora, mas enfim, foram três produções, a primeira e se desse certo, o teatro continuaria com o patrocínio da Shell por mais três produções.

Como deu tudo certo, foi uma loucura, todos os três espetáculos, tiveram mais três anos de patrocínio da Shell e nesses três anos a gente já estava começando a entrar em 1984, foi quando eu conheci o Gerald (Thomas). Ele apareceu no teatro porque foi convidado pelo Sérgio Brito. Em 1984, o Gerald fez uma visita ao teatro e foi um pânico, porque eu iria trabalhar pela primeira vez com um gringo, na minha cabeça. Ele estava morando em Nova lorque e eu só ouvia eles falando por telefone em inglês. - Nossa, eu não falo inglês, como é que vai se isso, vai ser um desespero. De repente, no dia da reunião, do encontro, ele chegou no teatro, cabeludo. Ele falava muito bem português e eu fui perguntar para o Jeferson que era o administrador do teatro. Ele disse: não, ele é brasileiro, mas mora em Nova lorque e fala inglês. Ti- 
vemos a primeira reunião e a história era fazer o espetáculo com Sérgio Brito, Ítalo Rossi e o Rubens Correia. Era o Quatro Vezes Beckett.

E dentro dessa história, um pouquinho antes disso, eu tive a experiência, o prazer de conceber uma luz. A primeira luz que eu criei, quem me chamou foi o Grupo Tapa, porque neste período de 1982 até 1985 para 1986 que foi o período que eu fiquei dentro do Teatro dos Quatro, eu tive outras montagens, e uma com o Grupo Tapa do Eduardo Tolentino. A primeira produção que eu fiz com eles foi - Viúva porem honesta, onde a luz era do Neném e do Aurélio, eu só operava, a segunda foi Pinóquio que era um infantil, eu também só operava, e na terceira produção deles, me chamaram para fazer a luz. Eles falaram esse é um projeto escola. $O$ teatro era o Teatro Ipanema, em Ipanema mesmo. E eu criei minha primeira luz com eles, nesse projeto, que no meu olhar ficava a desejar, mas para eles não. Disseram: não imagina, e a primeira, na próxima você vai ver. Eu falava vai ter próxima? E teve. Teve mais cinco na sequência. Depois disso, dessa sequência é que eu comecei, eu estava me preparando para a grande cena. Então, vamos chamar que eram espetáculos mais alternativos. Não era profissional, não estava no horário nobre.

E aí veio o Gerald, mas, antes disso, o Aurélio e o Neném, que eu quero deixar bem frisado, com todas as letras, é o meu pai, é o que, foram os caras que me ensinaram de verdade a brincadeira. Todo mundo acha que eu aprendi com o Gerald, eu não aprendi com o Gerald. O Gerald veio em uma etapa depois. As pessoas não têm noção, mas acho que agora, pela primeira vez isso vai ficar registrado, e as pessoas vão entender de verdade como é minha história com ele.

Fui em 1984 fazer esta história com o Gerald, começar essa história com o Gerald com o espetáculo Quatro Vezes Beckett. O que mais me fascinou foi que eu preparei uma luz, porque eu preparei uma geral. Porque era a base. A geral de frente era muito normal, alias nessa época a geral não podia faltar no espetáculo. Se não tivesse uma geral não era um espetáculo, se fosse só de focos era aquela coisa impressionista. Porque o Aurélio e o Neném eles faziam uma geral que era perfeita, de uma certa forma eles tinham uma visão do que era a televisão, que não podia ter sombra, que não podia ter nada, então era uma luz perfeita, não tinha sombra, você passava sem sombra. E eu caprichei nessa geral branca e o resto ele iria complementar com o que ele iria achar que fosse, mas a base eu queria deixar pronta para ele. Eu perguntei: Gerald vê se essa geral esta boa para você. Ele falou: geral? O que é geral? Eu: essa luz aqui. Ele: nossa, mas tem muita luz. Eu: mas você não trabalha com geral? Ele respondeu: Não, vamos fazer o seguinte, tira este, tira este, tira aquele, tira aquele, (apontando o dedo para o teto). E eu passei, quando eu passei tinha um buraco aqui, um buraco ali, e outro buraco aqui. Eu falei: mas é isso? Ele: É, é assim que eu trabalho. Minha luz é essa. Vamos começar.

A nossa parceria realmente começou a funcionar, e ele viu todo o meu esforço para a coisa acontecer, é que a gente teve que criar alguns refletores de iluminação para a coisa acontecer. Porque? Na época não tinha os elipsoidais, e uma das cenas do Quatro Vezes Beckett era o Ítalo Rossi fechado em uma cabine preta e só o rosto dele aparecendo, e mais nada. E o Gerald: Mas a gente não tem elipso, tu não consegues? Eu falei: Não, não consegue. A gente só tem PCs, Fresnel e Ribaltas. É isso que a gente trabalha, e, tirando os silibins da vida que se inventava. De uma forma geral 
você trabalhava com PCs, o Fresnel e o Set Light para fazer ciclorama e essa coisa toda. Ou senão, eu ainda peguei a época da ribalta de madeira e da gambiarra que era também de madeira. E muitas vezes a geral, troca de luzes, tudo era feito com essas gambiarras. Então, a gente não tinha mesmo. Ele falou: Mas, como é que a gente vai fazer para chegar nesse foco? Eu: Olha tem várias possibilidades, já indo na linha do Aurélio, do Neném da criação e falando. A gente pode pegar um PC e fazer um cone para poder aumentar um pouco mais a distância dele entre a lente e tentar fechar. Ele falou: Então perfeito, vamos fazer isso.

Mas o que que acontece, como o elipsoidal trabalha com duas lentes, sendo uma de foco e a outra para poder ajustar o grau. A gente não tinha isto, então o canudo estava assim e a lente mais ou menos a esta distância aqui assim (mostra com as mãos uns 25 centímetros), e aqui não tinha a segunda lente para poder corrigir. O filamento da lâmpada ficava no rosto da pessoa. Aí ele falou: Mas, como é que a gente vai fazer, e essa lente como fica. Eu: bom um difusor eu acho que resolve. Aí entrou um difusor na frente e pronto. Ele falou: Você nunca mais vai trabalhar com ninguém, daqui para a frente nós vamos ser parceiros de verdade. O que eu quero dizer com isso é, o Gerald ele é um artista plástico. Então ele desenhava, mas não sa-bia o que usar para fazer. Aí está o casamento. Começa minha universidade, porque ele tinha as ideias ou então vinha com as ideias prontas ou vinha com a ideias de es-petáculos. Muito tempo depois eu vim a saber sobre ele ver os espetáculos em Nova lorque e chegava aqui e me enlouquecia com isso. Porque ele falava dá para fazer. Eu perguntava dá para fazer como, você fez? Ele dizia "claro que fiz". Ele não fez, ele via

\section{Ele via uma outra ferramenta}

Ele via uma outra ferramenta chamada "Bob Wilson" e eu tinha que construir essa ferramenta para ele. Isso foi no ano de 1984, ele falou: Olha, eu estou voltando para Nova lorque, mas no ano que vem eu venho para o Brasil para fazer mais um espetáculo e você esta comigo nessa. E foi um sucesso. A gente começou a fazer, aquela geral cheia de buraco. O Quatro vezes Beckett dele era uma coisa muito soturna, era uma coisa da escuridão. Tendo os buracos, isso é o que ele veio me explicar muito depois, [passaria ] essa coisa da luz e não luz.

E eu nunca tinha trabalhado com a fumaça na época, e ele falou - Eu preciso da fumaça. Então, alugamos uma máquina, alugamos não, na época era cloretos e amônia que você colocava em uma latinha queimava aquilo e aquilo se espalhava no teatro, uma "delicia" (irônico).

\section{Vocês não sabiam ainda que era cancerígeno}

Não, ninguém sabia e se usava muito, muito, muito, muito. Qualquer coisa com fumaça, porque para colocar uma máquina de fumaça era muito caro e isso era o sistema mais barato, você fazia essa fumaça acontecer com 15 reais. 
Na luz dele o que mais me chamou a atenção, que até hoje eu chamo de "nada". Era um refletor que ele me pediu para pendurar (em uma lateral), e ele falou: neguinho eu não sei qual tipo de refletor, mas o que eu quero é isso aqui. Daí ele desenhou, só uma linha assim no caderno. Eu disse: Vamos usar o Fresnel porque eu acho que ele tem uma luz mais difusa, vai ter o resultado e não vai dar nenhuma bola lá no final, ele vai te deixar uma coisa mais limpa. Perguntei: Esse refletor vai onde? Ele disse: põe ele ali (Aponta uma diagonal lateral). Ele disse: vamos afinar. Colocar aonde? Na mesa? Na cadeira? Ele disse: em lugar nenhum, ele só vai cruzar o palco. Aí ele me deu uma linha. Eu pensei, mas não dá nem para ver isso, mas eu ainda não tinha visto com fumaça, eu só fiz a afinação, a gente afinou tudo e não tinha fumaça, eu não sabia que quando a fumaça entrasse, iria me dar um outro cenário, iria me dar uma outra história. E aquilo eu me lembro que, até hoje, foi uma coisa que me impressionou muito, porque eu estava muito acostumado, eu era da galera da geral, geral branca, geral vermelha, geral azul, geral rosa, geral âmbar, geral, geral, geral e alguns focos só.

E eu vi uma luz muito recortada, eu vi uma luz que até então eu não tinha esse conhecimento e nem tinha este entendimento. Outra coisa que mais me surpreendeu é que não tinha cor, e eu era viciado em cor, porque minha formação foi com cor. Tanto que eu tenho os truques do Aurélio até hoje na cabeça, que é colocar um foco de frente âmbar e um contraluz rosa. Que dá uma coisa que você fala: "Nossa, olha só o truque do cara", porque aqui do lado fica meio azulado (passa a mão no rosto), por causa da mistura, ou fica meio rosado.

Bom, eu vou falar só para deixar em registro. A luz na Pele Negra, eu sempre soube, o Aurélio e o Neném falavam que o âmbar é a melhor luz para cor na pele negra, para poder refletir na pele negra. Eu perguntei: porquê? Aurélio: Preste atenção, eu vou te ligar um verde e vou te fazer um foco em você com verde, olha como é que fica. E olha como é que fica com âmbar. Ele perguntou: Para você qual é a luz para a sua pele? Eu falei: Essa a branca, porque é essa que lê todas, esta é a mistura de todas as cores, esta é a mistura de todos os pigmentos. Não sei se eu estou certo Aurélio, mas eu acho que é isto. Ele falou assim: por um lado é, mas eu ainda continuo falando que se você colocar um âmbar, você vai realçar mais, você vai deixar mais brilho em uma pele negra.

Eu cresci com isso, e com o tempo eu vi que não. A luz que mais tem a ver com a pele, a luz para todos, é a branca. Eu não consigo ver nesse tema de ontem a luz da cor da pele negra porque isso daqui a pouco vai virar e a luz da pele amarela, e os Japoneses, tem que ter uma luz para os japoneses pois eles têm a pele amarela. Vai ter uma luz para os dinamarqueses que são super brancos.

Eu acho que o universo acadêmico tem umas brechas, ele caminha por umas brechas que o mercado não está pedindo isso. $O$ que eu vejo e o que eu entendo hoje, aos meus 54 anos dentro dessa história, trinta e quatro de bagagem, eu consigo entender o que é luz de show, o que é luz de infantil, eu consigo entender o que é luz de teatro experimental, eu consigo entender o que é luz [...], mas não consigo entender essa nova luz que está vindo.

Eu comecei a minha história com o Gerald, ele volta em 1985 e fala: vamos trabalhar no Quartett com a Tônia Carreiro e o Sérgio Brito, isso no teatro Laura Alvin 
em Ipanema. Nessa produção a gente caminha para o inicio da Companhia de Opera Seca. De 1985 para 1986 começa a surgir a Companhia de Opera Seca. O Gerald queria muito fazer uma Companhia no Brasil, e ele sempre falou para todo o mundo, "A gente vai viajar o mundo com essa companhia". O Gerald sempre foi muito bem articulado nesse sentido. Então fizemos o Quartett, depois ele começou a chamar a companhia, e foi aonde ele me convidou de verdade e disse: Wagner agora é para valer, mas nesse caso você vai ter de sair do Teatro dos Quatro. Ali era uma grana garantida, meu porto seguro, era tudo, e com o Gerald era uma aventura. Era uma aventura porque ele teve uma coisa bem negativa da mídia, a classe não abraçou o Gerald, porque ele chegou batendo muito pesado, ele chegou falando que o teatro nacional era uma merda, que o teatro nacional era só Plim Plim (Rede Globo).

Eu fazia parte desse teatro nacional, ainda mais no Teatro dos Quatro, eu trabalhava exatamente com todo o mundo da Rede Globo, então não tinha muito como fugir disso. Dentro dessa loucura, as pessoas iam se afastando de quem estava com ele. Eu fui perdendo muito amigos. Eles me viam como uma pessoa muito promissora para a iluminação, para poder decolar mesmo. Eu falei: está bom, mas eu preciso pensar um pouco, porque isso é um passo muito radical. Ele falou: É, mas você ainda continua trabalhando com o Aurélio com o Neném, fazendo as montagens. Eu disse: Sim, mas aí vai deixar, e nem sempre tem. As vezes esta ótima, as vezes tem dez montagens no mês e as vezes só tem uma montagem e acabou.

Eu falei: vamos lá. O que me instigou no Quartett foi que a Daniela (Thomas) construiu um cenário que era uma caixa e só tinha duas claraboias, mais ou menos de um $1,5 \mathrm{~m} \times 1,5 \mathrm{~m}$, as duas claraboias. A luz saia de dentro dessa claraboia. $O$ Gerald falou: eu preciso de uma luz muito, muito, mas muito forte para poder fazer isso, como é que a gente faz. Eu falei: Como é que vai ser o cenário? Ele falou: Vais ser isso aqui. Desenhou, e desenhou o feixe de luz saindo, mas sem o equipamento. Eu pensei meu deus, como é que a gente vai fazer isso. Se colocar um só não vai dar a potência que a gente precisa. Se colocar o elipsoidal também não, fiquei matutando, matutando. Fiz um quadrado e nesse quadrado tinham quatro fresneis de mil. A gente tinha um tubo de quatro mil watts saindo daquela coisa, e mostrei para ele. Ele falou: Exatamente isso que eu quero.

Eu sempre consegui entender muito o que o Gerald desenhava.

Eu acho que foi aí que começou uma parceria e uma troca muito grande.

A partir desse momento, ele falou: Wagner, você já está pronto para ir me dando as ideias, vamos trocar agora. Eu vou te preparando para depois você assumir isso sozinho e você ser o cara da luz.

E a gente foi trocando, ele foi me preparando, preparando, preparando e nunca chegava a hora da independência.

Porque sempre, até hoje, vem como registro ele desenhando e eu como assistente. Aconteceu no Quatro vezes Becket, aconteceu no Quartett, aconteceu na fase de Eletra com Creta, mas aí eu já dando um outro salto, partindo para contribuir. Na época a gente não tinha a lâmpada PAR em show, em teatro essa coisa toda. Aconteceu no Rock In Rio em 1985, trouxerem para fazer o show do Queen um refletor chamado Hi Light. O Hi Light nada mais é que uma lâmpada halógena, uma bolinha, que a gente até chamava de bolinha, dentro de uma carcaça de lâmpada PAR, com 
parabólica. [Esse material ficou no Brasil ao término do Rock in Rio]. E Hi Light encaixou muito bem para a coisa de teatro. Eu comecei a fazer as laterais dos nossos espetáculos, foi onde a gente trabalhou com tela pela primeira vez, com tule.

Primeiro, foi o tule que a Daniela criou, eram quatro corredores, com quatro telas, que se você jogasse luz na frente da tela ela virava uma parede, se você jogasse por dentro ela ficava invisível, ou seja ela ficava translucida. Você via através dessa tela. Essa mágica foi o que o Gerald me forçou a descobrir. Eu descobri de como iluminar esse cenário. A Hi light dava uma qualidade, um diferencial.

A gente já começou a ter os elipsoidais em 1986. Os elipsoidais já estavam no mercado, e a gente já fez os corredores com elipsoidais. Eu sempre determinei que material usar, eu sempre inventei como seria feito. Em Eletra com Creta ele já começa a ter uma confiança maior no meu trabalho. Ele fala: O próximo passo é fazer uma ópera, isso foi no final de 1986 para 1987, que foi o Navio Fantasma.

Começamos a fazer o Navio Fantasma, um cenário gigantesco da Daniela, uma produção maravilhosa. E foi a minha primeira ópera. O resultado foi maravilhoso. Como todos os espetáculos do Gerald foi uma polêmica, metade aplaudia, metade vaiava, metade saia e ia embora. Sempre foi assim, nunca foi diferente. A unanimidade, como dizia o Nelson Rodrigues, é burra. O Gerald sempre foi um diretor muito polêmico, e sempre teve uma coisa chamada qualidade; nos espetáculos dele era primordial ter qualidade. Ele falava: a gente sempre tem que ter um espetáculo com qualidade. Porque ele queria fazer com que este espetáculo chegasse na Europa, chegasse nos Estados Unidos.

Em 1987 a gente estreia, não final de 1986, a gente estreia o Navio Fantasma no Municipal do Rio de Janeiro, e o Yacoff Sarkovas aparece para produzir a Companhia de Ópera Seca, ser o produtor da Companhia. E ele chega e fala: Para isso vocês tem que mudar para São Paulo. Então, esse foi o segundo passo mais importante na brincadeira de realmente estar na estrada mesmo. O primeiro foi sair do Teatro dos Quatro, largar a minha zona de conforto; e, o segundo, foi largar praticamente a minha família e ir para uma nova cidade, hoje eu moro lá e amo aquela cidade.

A Companhia começou com Bete Coelho, Luiz Damasceno, Vera Holtz, Magali Biff, não Magali só entrou na trilogia, e Marcos Barreto, e estava esquecendo, claro, e a Maria Alice Vergueiro. E o Damasceno já era de São Paulo, a Bete já era de São Paulo. [Mudamos para São Paulo]. Seis meses dentro do hotel Excelsior (SP) e a gente foi estrear em 1987, inicio de 1987, no teatro do Antunes (Filho), no SESC da Consolação como Eletra com Creta, que foi um sucesso, foi uma coisa estrondosa.

Nesse processo, em São Paulo, eu tive a grande felicidade de conhecer duas pessoas. Domingos Quintiliano e Edivaldo Pereira que a gente chamava de Didi, e um tempo depois ele se foi. Quando eu cheguei no teatro eles estavam sentados na plateia e disseram: Oi, você é o Wagner? - Sou sim. - Então prazer eu sou o Mingo, eu sou o Didi, a gente queria muito trabalhar com você aqui nessa montagem. Eu falei: Mas, como assim, vocês não são aqui do teatro. Eles responderam: Não, não, a gente está começando a fazer luz, a aprender, e como a gente já sabe da história de vocês, do Gerald, essa coisa toda, dessa luz maravilhosa, a gente queria ver como que é o processo. Eu falei: Claro, vamos lá, vamos lá, vamos juntos. E nisso montamos o 
Electra em São Paulo, no Teatro Anchieta do Antunes, e depois veio o próximo passo que foi a Trilogia Kafka.

Essas duas pessoas, depois eu vim a conhecer, a conviver em São Pulo, eram o início dos Ligting Designer. Os dois trabalhavam com o Boi Voador na época, um grupo de São Paulo. Esses dois é que me conduziram para a cena paulista, que me apoiaram, que me levaram para os lugares, que me apresentaram a cena paulista. Gerald me colocou lá em São Pulo e depois ele voltou para Nova lorque, e a gente continuou, em São Paulo, com o espetáculo. Nessa época ele não fazia essa história de ficar dentro dos espetáculos.

Naquela época as temporadas eram longas, era uma coisa planejada para três, quatro, cinco meses, um ano, dois anos. Mas, eu não sei porque, por um lado aquilo que faz sucesso aqui, a gente vai se cansando e a gente mesmo acaba. Enquanto na Broadway você tem os espetáculos que duram trinta anos, quarenta anos. Você vai trocando elenco, mas a coisa continua, aqui não. O único espetáculo que eu vejo que é assim é o Trair e Coçar é Só Começar, Os Monólogos da Vagina. O resto não, o resto a gente acaba com eles. Porque a gente cansa dos espetáculos, de ficar fazendo a mesma coisa. Irma Vap voltou agora, foi um sucesso na época, estrondoso. Eles passaram sei lá, acho que oito ou seis anos fazendo.

Eles me levaram para a cena paulista, eles me apresentaram, eu comecei a conhecer os grupos, os diretores, os futuros diretores. Mas, não é fácil chegar em São Paulo. Depois desses seis meses do hotel Excelsior eu e o Marcos, a gente não tinha para onde ir. A gente não queria mais voltar para o Rio, a gente queria ficar. $E$ no processo da construção do cenário da Trilogia (Kafka), a gente dormia no teatro. Ninguém sabia, a gente dormia no cenário que a Daniela estava construindo, a gente tinha jornal para forrar no cenário, para poder dormir e para se cobrir também jornal. Isso estava funcionando, o nosso jogo estava funcionando bem. Terminava o ensaio e a gente combinava com o porteiro, a gente vai tomar um café ou uma cerveja e daqui a pouco a gente volta, que era o tempo de o pessoal ir embora, para a gente poder voltar e poder dormir no teatro. A gente ficou um mês nessa brincadeira, a gente ensaiou a trilogia três meses dentro desse espaço. Ficamos vinte dias nessa situação.

Até que um belo dia o Stocco, que fazia o espetáculo, [a Companhia cresceu acrescida de entradas e retiradas, ficamos em umas 10 pessoas], volta, porque esqueceu alguma coisa no camarim, e quando ele chega se depara com a cena - eu e o Marcos dormindo no canto, no cenário. Ele falou - O que vocês estão fazendo aqui? Ele percebeu e falou - Para tudo, agora, vem comigo. Ele morava em um apartamento quarto e sala, e a gente foi para a casa dele e ficamos na sala.

Depois que isso vazou, o Gerald não sabia, ninguém sabia. O Stocco ligou para o Gerald e falou: Os meninos estão dormindo no cenário. Aí pronto, no dia seguinte foi aquele estardalhaço, todo mundo falando, vem para minha casa e outras coisas. Eu e o marcos éramos muito ligados, aqueles irmãos de vida sabe, e luz e não luz, black and white. Ele já se foi (lagrimas). Bom, fechando essa história, o Gerald faz com que a produção tomasse providências, e alugaram um apartamento para a gente, mas não foi culpa da produção, foi nossa culpa e a gente começa a história. 


\section{Gostaríamos de saber um pouco mais sobre o Wagner pós Gerald}

[Viajei] pelo mundo com a Companhia de Ópera Seca. Aquela promessa que ele fez, ele cumpriu. Ele falou que iria levar a gente para o mundo e levou. Ele é o cara que me levou para o mundo, ele é o cara do meu doutorado, ele é o cara para mim. Em 1998 ou 1999, o meu ultimo espetáculo e eu sai [da Companhia]. Foi muito tempo juntos. Eu cansei de não chegar a minha vez dentro da estrutura do desenho, e nessa época eu já desenhava tudo mesmo. Era eu que dominava a brincadeira, eu só via as cenas e dizia, vamos fazer alguma coisa, e isso não me vinha como resposta.

Sair da Companhia de Ópera Seca foi muito sofrido, eu fiquei meio sem chão. Mas, eu já era uma pessoa muito requisitada, porque dentro desse processo eu já estava assinando luz fora, sozinho, já tinha feito outras coisas. Eu já tinha trabalhado com a Companhia em Quadrinhos, com a Bete Lopes, já tinha trabalhado com outros diretores. Eu já estava começando a entrar no meio, na cena paulistana, com respeito, independente.

A marca Gerald Tomas abriu portas e fechou portas, porque a estética, para muita gente era uma estética fria, então diziam, não ele só tem essa estética de fumaça, e até hoje tem que ter fumaça mesmo, eu sou o rei da fumaça.

Eu dou a grande virada, com a Daniela, Bete Coelho e mais uma galera que agora eu não me lembro. Eu desenho uma luz, minto, a luz eu tive que fracionar porque a gente estreou no Rio de Janeiro e eu não pude estar presente, eu estava em turnê, eu estava fazendo show, foi a minha fase show e nesta época eu estava com a Marina Lima. Eu estava em turnê e não conseguia estar na estreia do Rio. Eu fiz com a Michele Matalon e deixei tudo encaminhado para ela. Como eu não estava presente, ela resolveu que ela era a designer, e foi fazendo algumas coisas do jeito dela. Quando chegamos em São Paulo, e aí eu estava com tempo para fazer o espetáculo, eu sento e ai eu já estava bem seguro da história e falando, eu quero assim e assado. E a Michele falando: Não, mas é que eu fiz. Eu disse: o que você fez foi no Rio, aqui sou eu, quero assim, assado. Essa luz deu premio. Meu primeiro premio fora da história do Gerald, eu falei graças a deus que veio.

\section{Qual foi o espetáculo mesmo?}

Pentesiléias. O pós-Gerald foi uma coisa de muito conquista, com muitos espetáculos, muito trabalho árduo. Tem vários deles que me encantou muito. Um deles é a Companhia em Quadrinhos, que me deixou bem satisfeito com o trabalho. Um outro foi o show da Marina Lima, me deixou muito feliz assim de processo de trabalho. Ter saído do Gerald e ter, logo na sequencia, conseguido um premio. Eu larguei o Gerald na verdade, agora eu lembro direito, em 2001, 2002. Foi onde eu falei: Agora chega, agora chega de verdade e aí foi o final da coisa. Em 1998 eu estava na bola da vez e tal, dai agente parou e depois voltou.

Para fazer o ultimo que foi o Ventriloquist. Esse foi o derradeiro, em 2000 para 2001. Eu passei um ano meio perdido, diria que passei um ano em depressão mesmo, 
porque eu perdi meu chão, eu perdi minha família, eu perdi toda aquela minha zona de conforto, que fez parte da minha vida toda por treze anos, quatorze sei lá.

Fora isso começou a vir as coisas e todo mundo falava, cara, mas, qualquer um que entrava na Companhia Ópera Seca era o cara que fazia a luz. Eu tenho o exemplo disse, teve a Simone, teve a Aline, teve Caetano. Todos eles se intitulam de uma certa forma que conceberam a estética, mas a estética já estava pronta. Eles só reproduziam aquilo que o Gerald pedia, aquilo que eu participei, aquilo que eu ajudei a criar, a conceber como estética nossa. Isso nunca me incomodou, como nunca me incomodou eu sabendo que fazia a luz do Gerald por um lado e não tendo o crédito devido ali. [Eu] nunca cobrei isso, sempre deixei, porque eu achava que o custo benefício estava rolando de uma certa forma. Para mim o fazer não era a questão de ter o nome, e sim de ter o produto pronto. Eu fazia parte daquele produto, tanto que até hoje eu sou conhecido como o cara do Gerald, eu sou o designer, eu sou o assistente ou sei lá o que.

Mas, isso tem uma virada mais para a frente, quando nos fomos para a Alemanha, com a companhia da Bavária, a gente teve um contato de cinco anos lá, por isso que eu estou falando que o custo beneficio disso tudo, eu pesei muito. Na companhia da Bavária ele cisma que ele grava a luz, cisma que ele é o cara da luz, mas quem sempre montou a luz fui eu, como ele vai gravar uma luz que ele não sabe como que é. Os refletores estão pendurados e ele não sabia para que eram. Nisso a gente estava com o diretor técnico o Maicon Blanco, que mora em Nova lorque, ele é boliviano e mora em Nova lorque, trabalha com dança e tudo mais, é amigo do Gerald, e em todas as turnês internacionais ele fazia parte, o grupo aumentava mais para viajar, para as turnês.

O Gerald passou um dia tentando gravar a luz do espetáculo A Tempestade. $O$ Maicon chegou e falou: Gerald não está dando resultado não, não está acontecendo, não esta fluindo. Ou você deixa o Wagner fazer ou isso não vai acontecer. Ele falou: Não, é que eu tenho umas outras ideias. O Maicon falou assim: Você nunca teve estas outras ideias, quem sempre teve estas ideias foi o Wagner, quem vai fazer este espetáculo acontecer está aqui cara. Você não precisa, ele nunca te cobrou isso. Você está fazendo uma birra. E foi onde começou o processo todo da bola da vez. Você está fazendo uma birra desnecessária cara, você trouxe o cara para cá, todos os técnicos adoram o cara, sabem como lidar com ele, você não esta sabendo, você esta gritando.

O curioso que a cabine não ficava na caixa, ela ficava dois andares acima. Eles viam tudo através de uma tela, tudo era operado através desta tela. $E$ pelo sindicato eu não podia operar, eu só podia ficar em um canto dando deixas, falando para o cara, go (vai), go, go, porque já estava tudo em CUE, era só o tempo. Eu ficava de frente e o cara lá na cabine, no segundo andar desse teatro. Eu falei: porque eles não veem o espetáculo? Eles explicaram que era por causa da arquitetura, muito antiga que não tinha como quebrar, porque não podia e tal.

O Maicon falou para o Gerald: Cara e ai? A gente vai ficar muito tempo e os cara estão cobrando. Eu aprendi tanta coisa na Alemanha, também passei por muito detalhes, no sentido de que, a Daniela construiu um cenário que tinha oito metros de altura. As varas de luz iam até oito metros de altura, acima disso você tinha que pedir 
permissão para o sindicato, e o sindicato não permitia porque qualquer queda, plano de saúde e essa coisa toda. Eles não querem entrar com isso, porque você entra com um processo, é tudo muito complicado nesse sentido, é tudo muito rígido. Ninguém se preocupa aquí, mas deveria. Lá se preocupam e se preocupam muito.

Então, para poder afinar a luz, com oito metros tinha que estar as varas mais ou menos a um metro e meio a dois metros acima disso, para poder ter o foco com um pouco mais de abrangência para o cenário. Eles falaram, quem vai afinar, um disse eu não afino, outro disse eu não afino, eu não afino. Veio um cara de Viena, um técnico de Viena para poder afinar, porque o sindicato de Viena permitia afinar acima de dez metros.

Veio e afinou a luz e tudo mais. E na hora de gravar o Gerald entrou numa de que ele iria gravar, que ele iria gravar, que ele iria gravar. E o Maicon começou a falar: não maluco, deixa disso, esta demorando, esta demorando, o Wagner tem a luz na cabeça, quem sempre viu o seu espetáculo de frente, quem sempre esta com você do lado, quem sempre está falando para você como se faz as coisas, quando você pede os efeitos, quem é que te resolve os efeitos. Você sempre chegou para mim em Nova lorque falando isso. Ele estava conversando com o Gerald, eu estava a uma distância de tipo duas cadeiras do lado deles, então vamos lá.

O Gerald responde: Não, é porque agora eu vim com umas ideias na cabeça. Aí os caras começaram a falar com o Maicon, olha está demorado, está muito lento, está muito lento. A noite o Maicon chegou e falou: Gerald, vamos fazer uma coisa, amanhã você deixa o Wagner começar a gravar, se continuar muito lento aí você pega. O Gerald falou que tudo bem. Começamos, sentamos na mesa e comecei, claro que eu já sabia como que orquestrava aquela coisa toda, aquilo era meu controle, não era controle dele. Dentro disso, ele chega e me chama em um canto e fala: o Wagner eu acho que eu preciso te pedir desculpas pelo que eu acabei de fazer, você é o cara do meu espetáculo. É que é difícil para mim largar essa coisa, uma coisa que eu nunca tive, é difícil largar o que eu nunca tive, porque eu nunca fui o cara que realmente criei isso daqui. Eu nunca pensei esses efeitos, como colocar a maquina para fazer esses efeitos acontecerem. Me lembro que quando estava em São Paulo e você não pode vir para fazer Carmen comigo, mesmo assim você fez por telefone. Ele achava que se ele desenhasse todo mundo iria decodificar aquilo e iria transformar aquilo no que ele precisava. Ele me ligava e falava Wagner eu preciso fazer isso, isso, isso e eu dizia faz com isso, isso e isso. No dia seguinte eu perguntava e aí deu certo? Ele dizia deu certo sim, mas agora eu preciso saber como posso fazer isso, isso e isso. E é claro que ele me mandava por fax o que ele desenhava, ele falava assim, é isso, eu vou te mandar por fax. Eu fiquei horas na frente do fax com ele fazendo Carmem com Filtro. 
Ele lembra dessa história lá em Munique e fala: Eu me lembro que quando você estava no Rio e eu em São Paulo eu te ligava para falar como era para ser feito, mas o meu ego acabou com isso, o meu ego me fez esquecer isso. O Maicon Blanco me trouxe para a realidade, então eu quero te pedir milhões de desculpas e você é o cara que sempre fez essa história acontecer, sempre fez a minha luz.

É difícil falar do meu trabalho sem ter o Gerald porque ele me influenciou para eu ter o meu voo solo. Então, o pós-Wagner de Gerald vem premio, o pósWagner vem óperas, o pós-Wagner vem muitos trabalhos reconhecidos, o pós-Wagner vem show, o pós-Wagner vem Aline Santini. Esse é o meu legado, esse é o pós-Wagner. É. Aline Santini. Aline Santini para mim é o meu bebe, é a minha cria, é a menina do mercado de São Paulo hoje. É minha concorrente, estamos concorrendo até o prêmio Aplauso, vocês podem até dar o Google vocês vão ver, ela está lá. Está eu o Maneco, ela e mais alguém que eu não me lembro. Não é o Binho, o Binho era o prêmio Shell que a gente estava concorrendo com o Diluvio, eu ganhei concorrendo com ele. Não só ganhei dele, como ganhei da Aline também. E a Aline eu já estou na terceira etapa de dividir premio com ela. $E$ sempre o mestre ainda está vencendo, mas o mestre ainda vai ser batido por ela. Ela sempre fala que eu sou o pai. Para a Aline Santini eu sou o Gerald dela.

Ela também não deixa de falar do Wagner Pinto. Seria importante trazer essa menina para esse evento, ela é muito talentosa. Me incomoda um pouco as questões acadêmicas que vocês colocam. Me encanta, mas ao mesmo tempo me deixa meio sem noção e eu percebo muita teoria, muita teoria te deixa um pouco engessado para a criatividade. Talvez eu esteja falando besteira. Eu entendo que tenha que ter a história da luz, eu entendo que tenha o porque da luz, eu entendo tudo isso. Mas, eu sempre fiz sem ter tudo isso. Eu sempre fiz, a não ser os estágios que eu fiz no Metropolitan Ópera House, os estágios na Alemanha, mas nunca se aprofundou tanto, porque como a francesa ontem falou, existe escolas e escolas. Eu parei nesses estágios, nas escolas técnicas mesmo, então esta linguagem sempre foi o meu universo. Minha linguagem nunca foi muito teórica, claro alguns pontos aqui outro ali, mas sempre foi na prática. O que eu percebo, o que eu posso perceber hoje vendo Nádia, vendo Claudia de Bem, é que levaram elas um pouco nesse processo, porque se pensa muito. 
Você poderia nos apresentar um pouquinho sobre o Wagner até os dias de hoje para encerrarmos nossa entrevista?

O Wagner até os dias de hoje é meio complicado, é muita coisa. Mas assim, a fe-licidade que eu tenho. O Wagner pós-Gerald que eu acho que é o Wagner negro, que sobreviveu, dentro da brincadeira da iluminação. É o Wagner que realmente sabe conduzir um palco. É o Wagner que realmente tem a experiência de olhar para cima e falar, eu sei o que eu quero desse espaço, eu sei o que eu posso tirar desse espaço. E tive pessoas maravilhosas dentro desses processos Wagner. Conheci Denise Wa-inberg que é uma diretora maravilhosa, o próprio Antunes, o Yacoff Sarkovas tam-bém, foi uma pessoa que eu tive contato e o prazer de estar próximo. Mas, eu não sei muito como falar o Wagner pós porque eu nunca me enxerguei em situação de falar sobre a minha vida. Eu acho que eu preciso me preparar ainda mais, ter mais algumas coisas para poder falar. Mas, dentro dessa história toda, desse percurso todo, é o pra-zer de estar aqui. É o prazer de ter te conhecido Ivo. Alias, você me conheceu em uma situação de curso, de oficina junto com a Claudia em Porto Alegre. Que aliás, naquela época eu fazia muito mais do que hoje. Com o tempo eu fui deixando, porque eu sempre fui tímido, eu sempre falei para mim, você nem tem uma bagagem para isso, e naquela época eu nem tinha. $\mathrm{E}$ o Wagner pósGerald é um Wagner metido mesmo, é um Wagner arrogante, é um Wagner que se banca. Mas com conhecimento de como se entra em uma caixa, de como respeitar uma caixa, como respeitar o convívio de uma caixa, e com a ilusão de que um dia a gente pode ser ponta, primeiro mundomesmo. Ontem quando estava se falando da história do recorte, que o professor Ro-berto Gil ficou batendo nisso, a culpa no Brasil disso é do Ziembinski, e hoje a gente venera o Ziembinski, porque a gente trabalhava com ribalta e a gambiarra, a gente não tinha movimento de luz. Foi o Ziembinski que trouxe isso para a cena teatral brasileira. Então, se a gente vai buscar quem começou essa brincadeira no Brasil foi o Ziembinski. Se a gente vai buscar que começou a estética Geraldiana, foi o Ziem-binski, de uma certa forma. Não tinha fumaça, não tinha não sei o que, mas tinha os recortes, tinha os quadrados e outras coisas. Estou tentando só fazer um apanhado para finalizar.

Eu agradeço imensamente essa oportunidade de podermos trazer esse re-gistro da sua história. É extremamente importante, eu sempre fui um grande admirador do teu trabalho, eu sempre reconheci imensamente esse trabalho e a importância que você tem na história da iluminação cênica brasileira. Vamos encerrar por aqui e com certeza eu vou te pedir uma nova oportunidade para continuarmos esse bate papo. Muito obrigado. 